\title{
Improvement Of Public Service Quality Through District Partition Policy (A Study At Ciater Sub-District Resulted From Blossoming Of Jalancagak Sub-District Subang Regency West Java)
}

\author{
Rahman Mulyawan \\ Department of Government Science \\ Padjadjaran University, Bandung, Indonesia \\ Utang Suwaryo \\ Department of Government Science \\ Padjadjaran University, Bandung, Indonesia \\ Iyep Saefulrahman \\ Department of Government Science \\ Padjadjaran University, Bandung, Indonesia
}

\begin{abstract}
A requirement of adjacency between government and those who are governed is important if the government aim to provide a proper service. It reflects in one of the policy of Subang Regency Government called regional blossoming (pemekaran wilayah) that refers to the splitting up of their sub-districts (kecamatan) into multiple new territorial administrative units. The research is aimed at gaining a deep analysis on the policy through public service perspective and assisted by qualitative approach in the matter of data collection such as unstructured interview and documentation. The findings reveals the quality improvement of public service is an impact of regional blossoming in a certain local government. Furthermore, the regional blossoming policy also shows the more desirable presence of government amidst the public and also it is able to restrict a span of control and leadership of Camat as the determinant of adjacency embodiment between government and those who are governed and to embody a proper implementation of public service at once.
\end{abstract}

Keywords: public service, district partition, the closeness of the government and the governee, leadership

\section{INTRODUCTION}

To improve the quality of public service, the government has conducted various strategies, direct or indirect. In Indonesia, the selection of state policy regarding effort to bring the government closer to the society through regional blossoming has been conducted. It could be traced to various legislations regulating the submission and delegation of authority from central government to local government. Latest legislation about this matter is Law No. 23/2014 on Local Government.

In addition to regional blossoming, the government also set other policies to support the realization of better public service. Those policies are Regulation of Minister of Administrative and Bureaucratic Reform No. 16/2014 on Guidelines for Survey of Public Satisfaction on the Implementation of Public Service and No. 1/2015 on Guidelines for Evaluation of Public Service Implementation Performance. As for specific policy regulating public service in 
government environment especially administrative services in sub-district, the government issued a Regulation of Minister of Home Affairs No. 4/2010 on Guidelines for Integrated Administrative Service in Sub District.

For local level, through local policy, the government also conducts regional blossoming for sub district, administrative village, and village in their area. Many districts/cities issued a policy on this matter for those that have large area. Among others, Subang Regency West Java Province, based on Local Regulation of Subang Regency No. 3/2007, conducted blossoming for 8 sub districts, one of the districts is Jalancagak Sub-district that divided into Jalancagak and Ciater Sub districts. The policy of sub district blossoming chosen by government of Subang Regency in order to improve service to society as governee can be stated as an appropriate step since it allows better and quality public service at least the service will be simple easy, better, and faster. Nevertheless, the implementation of regional blossoming does not mean will improve the performance of government (sub district) in public service. In other words, the relationship between regional blossoming and the quality of public service is not always linear. It means that there are possibilities that after the blossoming, the quality of public service in sub district experiencing regional blossoming and in sub districts resulted from blossoming is not improved or constant or even decrease due to various reasons.

Based on the above background and to focusing the discussing on the purpose of study related to the quality of service in sub district resulted from regional blossoming, problems of study submitted were:

1. How is the public service in Ciater Sub district after being blomed from Jalancagak sub district in Subang Regency in 2015?

2. What factors influencing public service in Ciater Sub district after being bloomed from Jalancagak sub district in Subang Regency in 2015?

\section{PURPOSES AND OBJECTIVES}

In summary, the research aimed to find out quality improvement in public service in sub district resulted from regional blossoming conducted by Subang Regency in 2007. Specifically, the purposes of the study were:

1. To find out the quality of public service in 2015 in Ciater Sub district Subang Regency after being bloomed from Jalancagak Sub district

2. To analyze factors influencing the quality of public service as part of regional administration in 2015 in Ciater Sub district Subang Regency after being bloomed from Jalancagak Sub district

\section{LITERATURE REVIEW}

Generally, a government is understood as an institution or agency having formal power to do various activities in maintaining regularity and order in a society, providing all society's needs, and improving prosperity and autonomy of the society. It can be said that government refers to an organ or body or institution serves as the executor of state power ${ }^{1}$. Ndraha gave more specific limitation of government by stating that: "government is an organ having authority to process public service and obligated to process civil service for every one through government

\footnotetext{
${ }^{1}$ see Muchtar Affandi (1982) in his book "the Science of a State: a Comparison Study, gives explanation regarding to this government by linking it to power owned by the state. According to him, government, in the strict sense, refers to executive branch of state power executor. Government also defined as a technical organization along with its certain power to set and implement all affairs. In broad sense, it is defined as a whole series of institutions used by a group of people to govern and causes other to follow their order.
} 
relationship so that each member of related society receive it at needed time based on governee expectation" (Ndraha, 2003:6).

In order to be able to implement the authority and obligation, government could issue various policies that directly regulate the improvement of service quality and/or sets policies to bring government closer to governee through, for example, regional blossoming although it can be a dilemma option for the government. The regional blossoming policy is an important and significant option to improve the quality of government administration including in giving service to the society and allows the government to bring them closer to governee, on one side. On the other side, however, the policy becomes power seizure arena for some people in local level that could hamper the implementation of government due to different purpose of their regional blossoming.

Regional blossoming is generally understood as part of structuring autonomous region. Regarding structuring autonomous region, Djohan (2006) stated that it is hoped that regional blossoming give benefit for improvement in the implementation of local government functions in terms of service, empowerment as well as development. Therefore, regional blossoming policy should be in line with the need and demand of the society and feasibility condition of the area to be politically, economically, or socially partitioned. Related to this matter, Pratikno (2006) gave parameter limitation as follow:

Normatively, regional blossoming policy should be put in political reform frame of the government. In government function context, the policy should be put in the frame of improving the effectiveness of governance. Meanwhile, in the context of service function, regional blossoming should give positive contribution to the improvement of public service quality for all society groups. The blossoming is expected to give economic development acceleration enjoyed evenly by all areas and societies in Indonesia.

Empirically, structuring a region is not merely occurred in autonomous region (province, regency and city) but also in area such as sub district. It can be traced to legislations issued by government including Law No. 23/2014 on Local Government. Although it is not explicitly stated the concept or term of sub district blossoming, the law regulate the formation of sub district in a regency or city area. Refer to the formation of a region consisted of blossoming and corporation of areas, the formation of sub district surely can refer to sub district blossoming and corporation. The formation of sub district based on legislation is aimed to improve coordination of governance, public service, and empowerment of societies in the village or administrative village. The formation is conducted through local regulation that previously submitted to the ministry via governor as the representative of central government for approval before being approved.

Refer to administrative or technical dimension in regional blossoming as stated by Djohan (2006), it seems that sub district blossoming, based on geographical aspect, allows the improvement of purposes stated in Law 23/2014 since area to be regulated is increasingly narrow. Therefore, according to Mutholib (1987), as quoted by Djohan, regional blossoming is an appropriate option for more optimal service and more responsive government and easier public consultation due to the closeness of the government to the people they serve. In this case, service is important related to regional blossoming policy. Therefore, the success of government in serving the people has significant meaning since it will impact the recognition and trust of the people to the credibility and capability of the government in governance. 
Service, according to Moenir (2001), essentially, is a series of activities and process that regularly and continuously held. Saefullah (1999), using the term of public service, explain it as "service given to the society as a citizen or who legally be a resident of the country concerned. Therefore, in public service there are parties who serve and being served. In the context of government, Lonsdale, as quoted by Wirjatmi (1996), defined service as "something provided by a government or private organization since people generally are unable to fulfill them by themselves accept in collective way" (Wiratmi, 1996:6). It is in line with Wasistiono (2001) stated that "Public service is provision of service delivered by government or private parties on the behalf of government or private parties to the society with or without payment to fulfill the need and/or interest of the society (Wasistiono, 2001: 51-52) and Dwiyanto (2005) viewed public service concept as an activity conducted by government to fulfill their needs indicating that government must give service to the society. The service should be in accordance with the standard because it is the right of the society to receive quality service from the government.

Related to the limit of quality in service, Sampara Lukman explains that quality service should be implemented based on service standard that has been formalized as a service guideline. Service standard is a measure set as standardization of good service (Lukman, 1999:14). Another limit related to quality of public service is stated by Lovelock as quoted by Tjiptono that "quality of public service is the expected level of superiority and control above the level to fulfill customer's needs (Tjiptono, 1996:59). Supranto (1997), quoted from Kotler, stated that there are some dimensions in service quality called as steady service quality. Other dimensions used as measures for quality service are stated by Pasuraman, quoted by Tjiptono, which are: tangibles, reliability, responsiveness, assurance and empathy.

In order to achieve effective and efficient public service it is better that public service is conducted by local government through the implementation of decentralization. Through decentralization, each region will try to maximize all its government units. One of the government units is sub district, which is the tool of a region to build relationship between government and governee including in public service delivery.

In system perspective, there are none that can stand by itself without influencing and/or influenced by other. Refer to the opinion of Kaho (2010), looking at the implementation of special regional autonomy, there are at least four factors influencing the governance, namely: human - the executor, finance, tools or facilities and infrastructures, and organization and management needed in the governance. According to him, in order to conduct regional autonomy, or it can be said organizing local governance including public service, those four factors should be in good condition. Factors explained by Kaho are only some of the existing factors. There are other factors excluded in the identified factors. In addition, the division of the factors seems focused more on internal aspect, whereas external aspect - if exist - receive less portion. In the internal aspect of government, the explanation does not include socio cultural aspect despite its importance and significance in the context of social science could influence local governance, generally and public service, particularly.

\section{RESEARCH METHOD}

Refer to problems and purposes of the research, which was to find out social realities related to the quality of public service after regional blossoming and factors influencing it, the research used qualitative as its approach and explanation as its type of research. The basic consideration was that the approach and type of research were not only to give description on certain social symptom that became the focus of the research but also on how its relationship with other social symptoms as well as why and how the relationship occurred. 
Data collection techniques used consisted of, as stated by Sugiyono (2005), observation, documentation, and in depth interview or unstructured interview. To gain appropriate and profound information, selection of proper informant was an important matter. Informants were selected using purposive technique and it was set that the informants consisted of the head of Ciater Sub district, Ciater Sub district officials in charge of serving the society, village governments in Ciater Sub district, and village leaders in Ciater Sub district.

Data processing and analysis used were stages as stated by Sugiyono (2005), quoted from Miles and Huberman. Activities in data analysis were called multi-process data reduction focusing on selection, simplification, abstraction, and transformation of raw data obtained from field record; data display was started with information compilation into statements that allow for conclusion drawing; and conclusion drawing/verification was based on data reduction and display took place gradually from general conclusion in data reduction stage to data display stage and more specific to the real conclusion drawing stage.

\section{OBJECT, RESEARCH RESULT AND DISCUSSION \\ Public Service Post- Regional Blossoming in Ciater Sub District}

Location to study the quality of public service in sub district resulted from regional blossoming was Ciater Sub district, which is the result of regional blossoming from Jalancagak Sub district Subang Regency in 2007. The selection of the sub district as location of study was because the location of the sub district is in the border of Badung and Subang Regencies. The position has made Ciater as one of the farthest sub district from the capital city of Subang Regency. In addition, its geographical location ${ }^{2}$ with lots of mountains has made Ciater potential for tourism. With the potential, social change occurred in the area was very dynamic considering the significant outgoing and incoming people to and/or out from Ciater. Tourism potential would give room for the growth and development of tourism society in Ciater. Those problems, more or less, gave impact to the governance, in general and public service, in particular.

As a newly formed sub district, Ciater Sub district currently is in the condition of trying to arrange a responsive and accountable governance to achieve their vision, namely: "To Create Ciater Sub district as Traditional, Religious Society-Based and International Tourism Sub district". To achieve the vision, the sub district had set various missions to be conducted. Those missions were: improving the quality of office administration and personal resources and conducting public service. The number of population in Ciater Sub district in 2014 was 28.947 people with male of 14.568 people and female of 14.406 people, whereas population density was 630 people per kilo meter square. The population was distributed in 7 villages (Ciater: 5.599 people, Nagrak: 2.296 people, Cibeusi: 2832 people, Cibitung: 3.008 people, Sanca: 4.339 people, Palasari: 6583 people, Cisaat: 4.317 people). In Ciater Sub district, there are two villages with population above 700 people per Km2. Those villages are Palasari Village (1019 people /Km2) and Cibeusi Village (778 people/Km2), whereas village with the lowest population is Cibitung Village of 326 people per $\mathrm{Km} 2$.

Public service is part of governance as well as the main function of the existence of government. Therefore, Ciater Sub district, which is the local device of regional government of

2 See BPS Kab. Subang in the document of Ciater Sub district in Numbers 2015, Regional Statistic: Ciater Sub district 2015, and Job Description of Employees within OPD Ciater Sub district 
Subang Regency, has the obligation to fulfill the need of the people covered within the field of public service affairs. Legislation of governance in Ciater Sub district was based on Government Regulation No. 19/2008 on Sub district. Public service is part of the general tasks of government conducted by head of sub district. It means that the implementation of public service in sub district will be the responsibility of the head of sub district as a technical executive leader of the area. Services given by sub district (head of sub district) were those covered in its scope and/or those that have not been conducted by village and administrative village government. ${ }^{3}$ Those tasks related to public service were $^{4}$ : conducting planning for public service activities in sub district; conducting acceleration to achieve minimum service standard in its area; conducting guidance and supervision on the implementation of public service in sub district; conducting evaluation on the implementation of public service in sub district area; and reporting the implementation of public service activities in sub district area to a regent/mayor. In certain matters, such as licensing and recommendation, head of sub district also received responsibility to conduct the authority of government delegated by regent/mayor.

With the absence of new regulation on public service in particular, the implementation of public service in Ciater Sub district referred to the existing regulation, which is the Regulation of Minister of Home Affairs (Permendagri) No.4/2010 on Guidelines for Integrated Administrative Service in Sub District known as PATEN. The foundation for Ciater Sub district to refer to the minister regulation as the normative basic for the implementation of public service was also based on empirical level that there are more administrative services in public service delivery, either for licensing or non-licensing.

Despite the relatively positive of those policies, there were limitations in the implementation of public service in Ciater Sub district. Those limitations, among others, were related to the absence of regulation which sets on types of services provided by Ciater Sub district. Research result gave information that the sub district itself did not know exactly the legal basis regulating or specifying the types of services that should be provided by sub district. It was the normal condition since result of research on various policies issued by government, including Permendagri No. 4/2010 on PATEN indicated that there was none that set on types of service should be provided by sub district in general or those related to the implementation of PATEN itself. The Permendagri is merely divided the scope of service into licensing and non-licensing. Therefore, Ciater Sub district only conducted "the general" public service or those services that previously provided with the exception if there is other provisions such as in ID card (KTP) service.

With this absence of information on types of service, identification on types of service provided by Ciater Sub district to its people was needed. List of types of service was arranged based on research on various resources. The identification result is presented in the following table. 
Table Types of Public Service Provided in Ciater Sub District after Regional Blossoming

\begin{tabular}{|c|l|}
\hline NO & \multicolumn{1}{|c|}{ TYPES OF SERVICE } \\
\hline 1 & $\begin{array}{l}\text { The Making of Deed of Sale /APBH (Akta Pembagian Hak Bersama/ Deed of } \\
\text { Joint Right Division) }\end{array}$ \\
\hline 2 & Certificate of Inheritance (Surat Pernyataan Waris) \\
\hline 3 & ID Card (KTP) Process \\
\hline 4 & Note of Moved (Surat Pindah) \\
\hline 5 & Marriage Dispensation (Dispensasi Nikah/NA) \\
\hline 6 & Certificate of Domicile (Surat Keterangan Domisili) \\
\hline 7 & Certificate of Business Domicile (Surat Keterangan Domisili Usaha) \\
\hline 8 & Building Permit Legalization (Ijin Mendirikan Bangunan Pemutihan) \\
\hline 9 & Recommendation of Building Permit (IMB) \\
\hline 10 & Certificate of Underprivileged (SKTM) \\
\hline 11 & Certificate of Domicile (for people who want to go to pilgrimage) \\
\hline 12 & Family Card (KK) \\
\hline 13 & Birth Certificate (Akta Kelahiran) \\
\hline
\end{tabular}

Source: Research Result, 2015

The number of types of service identified that provided by Ciater Sub district could increase since there were other types of service provided in some sub districts. Those service, among others, were land use permit, SKCK (Police Clearance Report), Deed of Relinquishment of Rights on Land (Surat Keterangan Permohonan Pelepasan Hak Atas Tanah), seasonal resident identity card (Kartu Identitas Penduduk Musiman/KIPEM), Birth, Death, and Stillbirth Certificates, and Note of Moved between villages in sub district, between sub districts in regency, and between regencies in province. Since Ciater Sub district is a tourism area, it was likely that there would be additional new service to be provided related to that potential and condition.

Some informants (village government) explained that almost all types of service were provided but with different intensity. Public service arrangement was generally revolved around population administrative services such as KTP, KK, Note of Moved, Certificate of Domicile, SKTM, NA, and birth certificate. The information from this village government was in line with response from respondents as listed in the above table that put ID card process service in Ciater Sub district as the most needed service. Whereas, other services such as, IMB, deed of sale/APBH were conducted in the area of tourism villages, such as Palasari and Ciater Villages. The information was known since when people try to obtain the service, they had to have cover letter from the village and after that they will arrange the rest of the process. Regarding this matter, village government usually conducted the activities collectively. However, for urgent matter such as SKTM for requirement at the hospital, one of village (village secretary) will arrange it immediately.

Data presented in Table 1 only indicated that Ciater Sub district at least had those 13 types of service provided. The data cannot be the main indicator to appraise the quality of public service. The data, however, could be used as consideration by the sub district to prepare service strategy, such as for better ID card process. For example, by preparing more quality (effective and efficient) facilities and infrastructures (equipment), comfortable lounge that accommodate more people, and additional staff, and so on. 
The sub district was only 8 years but it received positive rating from the society in terms of the implementation of public service and it was certainly a great achievement for the administrator, especially the head of sub district, despite the existing limitation, such as rented office building. The situation, clearly, brought difficulty for the head of sub district and his staffs to conduct more representative and conducive space structuring for governance and public service. Therefore, it was reasonable for some informants to state that based on tangible aspect, such as the space for serving the public, the space was not clean and uncomfortable as well as the facilities were inadequate and less support for the service. In this case, people still expected the availability of sufficient facilities to give conducive and representative service. The availability of facilities consisted of rooms with its facilities and infrastructures would give comfort to the society. On the contrary, if the rooms were less conducive, public service conducted by the sub district would be poor due to the absence of the aspect. In addition, the far distance that should be taken by the resident to sub district office adding the demand for the availability of space and facilities. In the perspective of serving and reinventing government, the society is a consumer and their comfort in activities would be the main concern for the government, in this case, Ciater Sub district.

Limitation in tangible aspect was fortunately could be covered by the administrators (sub district officials) who considered as skillful by the informants. It was based on their skill and dexterity in serving the society. The skills needed by the officials to perform public service were not as complex as those in performing development and empowerment function, especially for officials who worked in technical institution such as department and agency. The ability in serving the society was administrative in nature and referred more to the ability of the officials to operate the tools to give satisfying service in terms of the speed, accuracy and dexterity. Therefore, the officials could show aspect of reliability.

The quality of service also related to the responsiveness of the officials on every issue faced in the implementation of public service. Regarding this aspect, Ciater sub district had good responsiveness. The appreciation was related to the various efforts of improvement conducted by the sub district to achieve quality public service. One of their efforts was by preparing "a room" for "integrated service". The room was built by the head of sub district to accelerate service delivery. Although it was a simple room but it was really helpful for the service delivery as a whole since the delivery could be done at that moment, which means efficiency in service delivery. Complaints were still occurred regarding to service room; however, the condition was unavoidable since the office was rented and belong to Cisaat Village that previously was a public market. In this condition, head of sub district had no discretion to conduct office structuring.

The policy of the head of sub district to prepare service "room" was related to his sensitivity to the aspiration (complaints and suggestions) from the people that submitted directly or through village government. It means that the head of sub district opened "other areas" for dialogue or communication room between the government and the governee as well as between the leader and the led. The room had made problems faced by or complaints from society could be solved immediately. The strategy conducted by the head of sub district to build communication was by conducting "weekly routine activity". In addition to information exchange, in the communication room, the information itself would be updated continuously. The same was occurred for all complaints or aspiration as well as suggestions brought by the society. This "communication room", which was the strategy of the head of sub district, had made respondents to give appraisal that a place to collect suggestions, inputs, and complaints brought by the society were available. The communication room had made village government 
as the first party in service delivery in Ciater Sub district and to give information immediately to the residents related to the procedures or requirements to get the service.

The third aspect in quality service that seemed to have significant impact in the appraisal of the quality of service provided by the sub district was assurance. Communication room that initially built by the head of sub district as a strategy to responds every problem, turned out to be a strategy that indirectly could build certainty, trust, and security among the society toward public service conducted by the sub district as a sub district resulted from regional blossoming. Nevertheless, complaints regarding the aspect were exist regarding uncertainty in the amount of fee paid by society to get the service and time to complete the process (for ID card (KTP), family card (KK), and others). The uncertainty was actually caused by the society itself who turned out often gave "administration fee" to the officials (especially in the village) in different amount to get their service done. However, the "administration fee", actually, was neither existed nor required. It was the society itself who gave the fee. To get SKTM, village official never accepted any "administration fee"; however, they would accept the fee for other administrative matters that required them to go to sub district or local government that supposed to be done by the society itself. Meanwhile, the uncertainty regarding time to complete the service was not occurred in the sub district because the final completions for almost all public services that are administrative were at Subang Regency.

Quality public service delivery must fulfill empathy aspect. The aspect is related to the attitude of officials to build relationship with the society. The relationship will be easily built if the officials have better understanding on problems faced by the society or their needs. Based on research result, it was known that generally informants rated the officials at Ciater Sub district to have good empathy since they were always friendly while serving the society and had better deep understanding in problems faced in the society. The appraisal was based on the aspect of assurance as explained previously as well as other four aspects. Ciater Sub district had the ability to build good relationship with the society. It means that empathy would not be the weakness point for the sub district as well as gave problem in the quality public service to be achieved by the sub district. The confidence in the ability of the sub district to build relationship with the society that in the end could build empathy to the officials was actually could be traced when the head of the sub district built "communication room" between the government and the governee and between the leader and the led (subordinate). Through the room, the development of officials' attitude in serving the society could be socialized continuously.

In addition, through the room, the head of sub district could also build sensitivity among the officials toward problems faced by the society, in public service or in their life as well as in governance issues. Therefore, regarding the attitude and sensitivity of the officials, respondents gave positive value. The table indicates that respondents did not put attitude and sensitivity as one of reasons for unsatisfactory public service at Ciater Sub district.

\section{Determinants in Public Service Delivery in Ciater Sub district}

Refer to previous explanation we can see some factors as determinants in public service delivery in Ciater Sub district after regional blossoming with Jalancagak Sub district. Generally, those factors could be divided into two: supporting and hampering the achievement of public service quality. 


\section{Supporting Factors}

With no intention of ruling out other factors, the leadership of the head of sub district was the main factor in the success of governance and public service in Ciater Sub district. His strategy in building relationship between the government and the governee as well as between the leader and the led was the key for quality service delivered. The strategy was the availability of intense "communication room" that allow exchange and update information regarding the arrangement and completion of public service needed by the society.

The communication room built by the head of sub district was indirectly cultivated the spirit among village government to have better, productive, responsive, and accountable governance and public service. Research result gives description on village government in terms of sufficient quality public service. It can be seen when village government (officials) who gave security and comfort in receiving people who wanted to get their documents (such as cover letter to community health center, sub district, and others). The village government often gave explanation related the next procedures taken for the service after completion at the village.

Refer to the position of sub district as set in Law No. 23/2014 on Local Government, it can be said that Ciater Sub district had succeeded in improving coordination in governance and public service in their working area. The success could not be separated from the ability of the head of sub district in performing his duties well as stated in the law or in particularly, those duties related to service as arranged by Permendagri No. 4/2010 on Guidelines for Integrated Administrative Service in Sub District. In this case, the head of sub district was able to lead, coordinate, control the implementation of integrated administrative service in the sub district through simple "integrated service room".

Although the research result indicated a sufficient quality of public service delivery, this rating was considered as a good achievement since the sub district was newly formed and its infrastructures could not fully support the delivery (such as rented office building). The head of sub district also deserved to have appreciation in performing his duties and obligations in implementing sensitive and responsive leadership; thus, any suggestions and/or critics/complaints from the society were received for improvement and self-evaluation.

\section{Limiting Factors}

Research result indicated that public service delivery in Ciater Sub district was not fully satisfied the society. In other words, the service conducted was in the level of fairly good (in sufficient quality). However, the rating was not merely due to the inability of the sub district in the delivery. Generally, the rating was caused by factors beyond the power of the sub district, as follow:

1. The long distance taken to go to Ciater Sub district location

The policy of Subang Regency by partitioning some sub districts in its area was aimed to bring the government closer to its people. In concrete, it was to close the distance for the society to government office to arrange various administration needs. The policy was implemented in order to conduct all functions of government existence, namely: service, development, and empowerment. In order to do the function better, one of ways was by bring them closer to the society.

In Ciater Sub district case, the distance from community residence to sub district office was far. Therefore, it would take more time and money for them to arrange administration needs. It could be doubled if the arrangement could not be done in one time or one day. Some respondents stated that if they used short cut the distance would be closer to the previous sub district office (Jalancagak Sub district). It was due to the location of the office that is not in the 
center area of the seven villages of its working area. The village office, currently, is located in the border of West Badung - Subang in Cisaat Village area.

2. Service Infrastructure (Sub district Building Office) was not owned by the government After 8 (eight) years post-partition Jalancagak Sub district, the office of Ciater Sub district was still rented. From information, it was known that the building was previously used as public market. The building, physically, was still fit for use. However, based on the area and layout, the building was not conducive to support the governance and quality public service.

For example, integrated service room had to share with lounge room that also functioned as a room for office guests. Therefore, the serving room has limited space with only table and chair. When they only served one or two people the room is still comfortable. However, in certain time when many people wanted to arrange their administration needs, the room became uncomfortable since it would be crowded.

Knowing that the building did not own by the government (Ciater Sub district) and was not for office building, the head of sub district found difficulties in arranging the space to be more representative and conducive. In addition, the available rooms were limited since the building was not large. Therefore, integrated service room used the guest room that also functioned as a lounge; consequently, comfort did not exist during service delivery. This was something that the people complained about. They compared the office building with other sub district office buildings or Jalancagak Sub district.

3. Limitation of sub district's authority as public service provider

The limitation of sub district's authority was another factor causing public service delivery in Ciater Sub district was rated as fairly satisfactory or in sufficient quality. The authority in question was the authority to handle various types of service to be completed in the sub district alone. In some services, such as ID card, the process would involve local government, in this case the related agencies. Consequently, people who needed the ID card should prepare more time and money. It was differed to previous period where the ID card could be completed at the sub district only.

4. Uncertainty in the process and completion of services causing different time and money required

The contribution of Ciater Sub district regarding uncertainty in the process and completion of service was related to time and fee needed to complete the process. The length of time was due to the officials of sub district who needed to wait some people to get the same service (not only 1 or 2 people) so it would reduce the cost (transportation to the office of local government/Pemda) needed to process it. In addition, it was also for the sake of time efficiency because the time needed to go to the office of Subang Pemda could be used by the officials to complete their duties. Meanwhile, the fee for administration service at the sub district has been set with clear regulation. Fee for certain services has been set by local government (Pemda); whereas, there were some services that free of charge. Uncertainty in the amount of fee occurred since some people asked the sub district official to help them to get their needs in certain services that sometimes did not require their presence. To replace the transportation fee, they would give money with no particular regulation in the amount given. Therefore, each people would give different fee depended on their own willingness. 
On the other side, the practice could give negative image to sub district official and the sub district itself. It seemed that there was brokering practice or "service bureau" at the sub district. Empirically, research result indicated the image that was informed during questionnaire distribution. The negative image that also occurred was injustice in service, for those people who gave bigger fee to the officials the process would be faster compare to those who gave smaller fee. Using logic and mathematic calculation (beyond norms and laws), this event was normal. If we related it with the distance that must be taken by the official to help arrange the administration asked by the society, the energy should also be considered. It means that based on the calculation, the "service bureau" was not enough to cover the cost of transportation since a consideration should also be given to other aspects, such as time, energy, and else. Therefore, it was normal that people who gave bigger fee would have their process to be completed immediately at Pemda since all the cost required was covered. Regardless the calculation and logic consideration, based on government ethic, the practice could not be justified. It was better for the society to arrange and complete their administration matters up to the Pemda office by themselves. The sub district official only served them based on those set by the law. In the end, the decision would be a big burden for small communities since they had to spend more money as well as more time that should be used for them to make a living. Considering that Ciater Sub district was part of Local Government of Subang Regency, the local government should also look for the solution.

\section{Conclusion}

\section{CONCLUSION AND SUGGESTION}

Based on the previous description, conclusion could be draw related to the quality of public service in Ciater Sub district post-partition of Jalancagak Sub district Subang Regency, as follow:

1. Public service conducted by Ciater Sub district post-partition consisted of various types of service. There were 13 types of service identified, namely: ID card (KTP) process, family card (KK), Certificate of Inheritance, deed of sale, building permit (IMB), and so on. Generally, the sub district was able to deliver those services although it needed improvement in some matters, such as the requirements, certainty in the completion of the process, and so on. However, those problems were understandable since the sub district was newly formed in 2007. The establishment of the sub district gave positive impact to the creation of quality governance, in general and public service, in particular. It was due to the narrowing span of control of the governance and public service thus closer relationship between the government and the governee. The closeness gave opportunity to the government of Subang Regency to improve the quality of the governance and public service through the existing government units at the sub district. Therefore, it can be stated that the policy of sub district blossoming was relevant as a strategy to improve the quality of public service.

2. The success of Ciater Sub district that able to perform quality public service cannot be separated from the leadership of the head of sub district who succeeded in managing and resolving all limitations faced by the new sub district. Communication room built between the government and the governee as well as between the leader and the led was an appropriate strategy in achieving quality public service. However, there were some factors that hampering the achievement of more quality public service. Those factors were related to the far distance of sub district office from the villagers, sub district infrastructures (office building) that did not own by the government thus brought difficulties in structuring conducive and representative service rooms, uncertainty in the arrangement and completion of service, and the limitation in sub district function and authority in the implementation of service function. 


\section{Suggestions}

Refer to the above conclusion there were some matters where the government of Subang Regency need to pay attention on in order to improve the quality of governance and public service.

1. The improvement of public service quality through district (sub district) partition policy can still be a consideration for Subang Regency Government since it could give an opportunity to improve the quality of public service as well as indirectly, it could build closer relationship with those being governed. In addition, span of control as part of government management is narrowing thus coordination, development, and empowerment in realizing the goal of governing can be effectively and efficiently done.

2. The limiting factors in the implementation of public service in Ciater Sub district were mostly caused by external factors. Therefore, factors require attention from local government and regional house of representative of Subang Regency regarding:

a. Appropriate government apparatus placement to fill strategic position (such as head of sub district) based on merit system

b. The availability of government office for conducive and representative sub district office adjusted to the geographical condition of the sub district

c. Sub district, as a bridge between Subang Regency Government and the society, needs to have addition function and authority related to the arrangement and completion of public service, especially those related to the effort in shortening the service process only up to the sub district

d. Simplifying the requirements in arranging and completing the service by creating a card (such as smart card) or else that cover all requirements need to be fulfilled by the society. The simplification could also be done by simplifying the bureaucracy and applying proactive service, which is assigning related agency in public service delivery to visit each sub district in Subang Regency regulary. It is better that the proactive service is conducted in the villages. In addition, it will improve the easiness and speed of service, which means improving the quality of public service. The strategy could also improve the quality of relationship between the government and the governee.

\section{References}

Djohan, Djohermansyah. 2006. Mengkaji Kembali Konsep Pemekaran Daerah Otonom dalam Indra J. Piliang (epilog). 2006.Blue Print Otonomi Daerah Indonesia.Jakarta: Yayasan Harkat Bangsa bekerjasama dengan Partnership for Governance Reform in Indonesia dan European Union.

Kaho, Josep Riwu. 2010. Prospek Otonomi Daerah di Negara Republik Indonesia.Identifikasi Beberapa Faktor Yang Mempengaruhi Penyelenggaraannya. Jakarta:Rajawali Pers

Malo, Manasse dan Sri Trisnoningtias. (tanpa tahun). Metode Penelitian Masyarakat. Jakarta: Pusat Antar Universitas Ilmu-ilmu Sosial Universitas Indonesia

Moenir, H.A.S. 1996. Manajemen Pelayanan Umum di Indonesia. Jakarta: Bina Aksara

Ndraha, Taliziduhu. 2003. Kybernologi cet 1. Jakarta: Rineka Cipta.

Nurcholis, Hanif. 2005. Teori dan Praktek Pemerintahan dan Otonomi Daerah. Jakarta: Grasindo

Pratikno. 2006. Politik Kebijakan Pemekaran Daerah dalam Indra J. Piliang (epilog). 2006.Blue Print Otonomi Daerah Indonesia. Jakarta: Yayasan Harkat Bangsa bekerjasama dengan Partnership for Governance Reform in Indonesia dan European Union.

Rasyd, Ryass. 2000. Makna Pemerintahan Tinjauan dari Segi Etika dan Kepemimpinan. Jakarta: Yarsif Watampone. 
Saefullah, A.D. 1999. Konsep dan Metode Pelayanan Umum yang Baik dalam Jurnal Ilmu-ilmu Sosial dan Ilmu Politik Vol 1 Tahun 1999.

Sugiyono. 2005. Memahami Penelitian Kualitatif. Bandung: Alfabeta

Tjiptono, Fandy. 2000. Manajemen Jasa: Yogyakarta: Penerbit Andi

Wasistiono, Sadu. 2001. Kapita Selekta Manajemen Pemerintahan Daerah. Sumedang: Alqoprint

Wirjatmi, Endang. 1996. Manajemen Pelayanan Umum di Indonesia. Jakarta: Citra Naga Rajawali Press

Peraturan Perundang-undangan:

Undang-undang No. 23 Tahun 2014 Tentang Pemerintahan Daerah

Peraturan Pemerintahan No. 9 Tahun 2008 Tentang Kecamatan

Peraturan Menteri Dalam Negeri No. 4 Tahun 2010 Tentang Pedoman Pelayanan Administrasi Terpadu Kecamatan 